\title{
Earthquake-Triggered Subaerial Landslides that Caused Large Scale Fjord Sediment Deformation: Combined Subaerial and Submarine Studies of the 2007 Aysén Fjord Event, Chile
}

\author{
Reginald L. Hermanns, Sergio A. Sepúlveda, Galderic Lastras, David Amblas, \\ Miquel Canals, María Azpiroz, Ignacio Bascuñán, Antonio M. Calafat, \\ Paul Duhart, Jaime Frigola, Olaia Iglesias, Philipp Kempf, Sara Lafuerza, \\ Oddvar Longva, Aaron Micallef, Thierry Oppikofer, Xavier Rayo, \\ Gabriel Vargas, and Freddy Yugsi Molina
}

\begin{abstract}
On 21 April $2007\left(\mathrm{M}_{\mathrm{w}}\right.$ 6.2) an earthquake triggered more than 500 landslides near the epicenter along the Aysén fjord, Chile. One of the major failures occurred at the Punta Cola Valley involving a volume of 20.9 million cubic meters of rock. The main rockslide was followed by a rock/debris avalanche involving talus and glacio-fluvial deposits in the slope toe and valley floor that added a volume of 7.3 million cubic meters as entrained material. About half of the material involved in the rockslide-debris avalanche reached the shoreline and entered the fjord pushing deltaic deposits offshore while inducing a shoreline retreat of $100 \mathrm{~m}$. The impact of the debris avalanche deformed an area of $7.6 \mathrm{~km}^{2}$ of the otherwise featureless and smooth sedimented fjord floor. The central part of the deformed area is currently deeper with respect to the undeformed floor, which suggests that between 1 and $10 \mathrm{~m}$ of sediment were eroded from an area of $1.85 \mathrm{~km}^{2}$ due to the direct impact of the avalanche. The combination of debris avalanche impact of this and other landslides, subaqueous failures and fjord floor deformation generated a series of displacement waves within the fjord with several meters to tens of meters high run-up along the shoreline.
\end{abstract}

R. L. Hermanns $(\bowtie) \cdot$ O. Longva $\cdot$ T. Oppikofer $\cdot$ F. Y. Molina Geological Survey of Norway, P.O. Box 6315, 7491 Sluppen,

Trondheim, Norway

e-mail: Reginald.hermanns@ngu.no

S. A. Sepúlveda · G. Vargas

Universidad de Chile, Plaza Ercilla 803, Santiago, Chile

G. Lastras · D. Amblas · M. Canals · M. Azpiroz · A. M. Calafat

J. Frigola $\cdot$ O. Iglesias $\cdot$ S. Lafuerza $\cdot$ X. Rayo

GRC Geociències Marines, Universitat de Barcelona, Carrer

Martí i Franquès s/n, 08028 Barcelona, Spain

I. Bascuñán · P. Duhart

Servicio Nacional de Geología y Minería, La Paz 406,

Puerto Varas, Chile

P. Kempf

Renard Centre of Marine Geology, Ghent University, Krijgslaan

281/S8, 9000 Ghent, Belgium

A. Micallef

University of Malta, Msida, MSD 2080, Malta 


\section{Keywords}

Rock avalanche $\cdot$ Earthquake trigger $\bullet$ Displacement wave $\bullet$ Fjord sediment deformation

\subsection{Introduction and Geological Setting}

A number of events show that devastating displacement waves have occurred from subaerial landslides (e.g. Hendron and Patton 1987; Blikra et al. 2006). In some regions of the world, such as the fjords of western Norway, displacement waves generated by subaerial rock avalanches have taken place several times during the last century often resulting in large loss of life (e.g., Blikra et al. 2006; Hermanns et al. 2012). In addition, submarine landslides have also been identified as tsunami sources (e.g., Tappin et al. 2008). However, subaerial rock avalanches impacting a water body with synchronic submarine landslides and soft-sediment deformation have not been investigated as detailed topographic and bathymetric data from the same event are not usually available. In this contribution we present the first detailed combined high resolution data set of topographic and bathymetric data of the Punta Cola rockslide debris avalanche that entered the Aysén fjord on April 21st, 2007.
In early 2007, after an unusual four-month period of moderate seismicity in the Aysén Fjord $\left(45.5^{\circ} \mathrm{S}\right.$, Chilean Patagonia), a Mw 6.2 earthquake struck the region. This seismic episode was related to tectonic activity along the regional, strike-slip Liquiñe-Ofqui Fault Zone (LOFZ), which accommodates the oblique convergence of the Nazca and South American plates. The mainshock (21st April 2007) was localized in one of the several branches of the LOFZ that crosses the fjord, and triggered hundreds of subaerial landslides in the epicentral area along the fjord and surroundings. Slope failure occurred on the glacially oversteepened slopes composed of granitic rocks of the North Patagonian Batholith and within the volcanic soil layer (Sepúlveda et al. 2010). The largest rock slides and rock avalanches that entered the fjord water mass generated a series of displacement waves that together with debris flows caused ten fatalities and severe damage to the salmon industry, which is the most important economic activity of the area (Naranjo et al. 2009; Sepúlveda and Serey 2009).
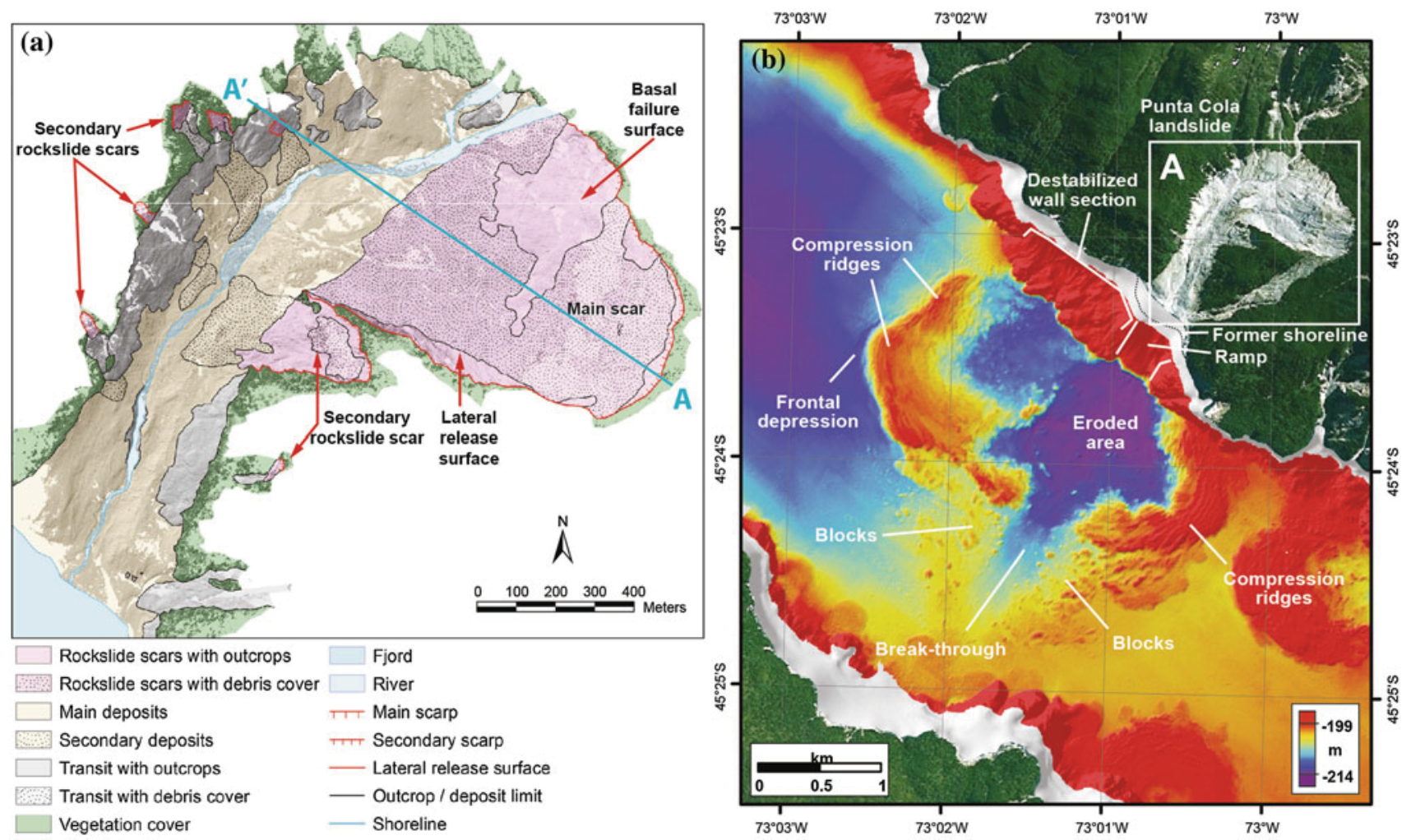

Fig. 14.1 The Punta Cola subaerial and submarine landslide. a TLS mapping of the Punta Cola rockslide. $A-A^{\prime}$ marks the profile location of Fig. 14.2. b Combined satellite imagery and bathymetric map of the Punta Cola landslide area, showing its imprint in the fjord floor 


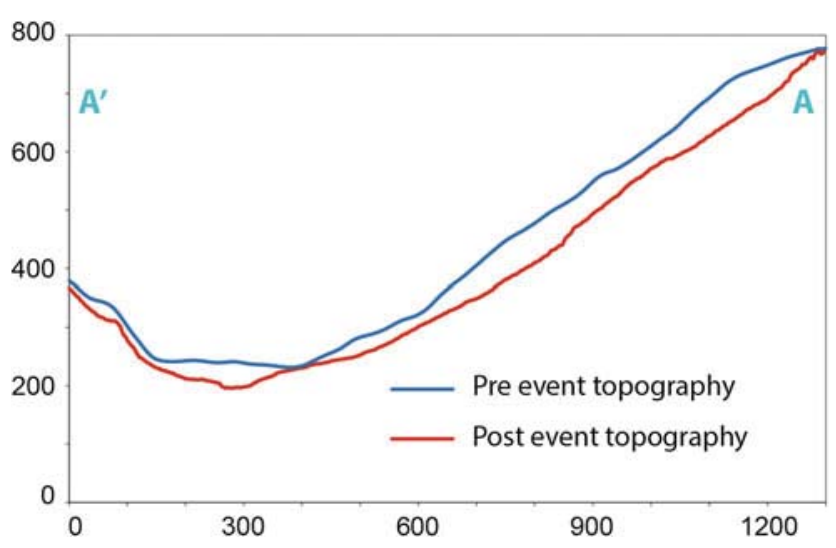

Fig. 14.2 Topographical profiles along main rock slope failure into the Punta Cola valley (location shown in Fig. 14.1). The pre event topography is based upon the photogrammetric DEM with $7 \mathrm{~m}$ pixel resolution and the post event topography is based upon the DEM obtained by TLS with an average point density of 35 points $/ \mathrm{m}^{2}$. Note that topography got reduced along the slope by the rock slope failure and in the valley by entrainment of debris into the debris avalanche (see text for details)

The Punta Cola rockslide failure sourced from a NW facing 220-750 m high slope within the Punta Cola valley $1-1.75 \mathrm{~km}$ away from the water front. It descended along the Punta Cola valley down to the waterline and entered the Aysén fjord (Sepúlveda and Serey 2009) (Fig. 14.1a). The rockslide resulted in the deformation of the fjord floor sediments in a large area in front of the Punta Cola valley (Van Daele et al. 2013; Lastras et al. 2013). Modeling of the displacement wave has been carried out, reproducing near source run-up heights observed on islands in the fjord, but the modeled and observed run-up in more distal areas differ by a factor 2-3 (Scheele et al. 2013).

\subsection{Methods}

Detailed Terrestrial Laser Scanning (TLS) was carried out in the Punta Cola valley in January 2010 in order to document the precise post failure morphology of the valley and obtain a volume estimate of the rockslide (Oppikofer et al. 2012). The post failure DEM obtained by TLS was built from 58 scans and covered an total area of $1.4 \mathrm{~km}^{2}$ with an average point density of 35 points $/ \mathrm{m}^{2}$. The pre failure DEM reconstructed by photogrammetry based upon aerial photography and had a pixel resolution of $7 \mathrm{~m}$ (Yugsi Molina et al. 2012) (Fig. 14.2).

In order to study the impact of this subaerial landslide on the ocean sediments, swath bathymetry data was obtained during the DETSUFA cruise onboard BIO Hespérides in March 2013 with a Simrad EM-1002 multibeam echosounder. Data were tide-corrected and processed with Caris HIPS and SIPS, yielding a final $4 \mathrm{~m}$ cell-size DEM.

\subsection{Results}

Based upon the TLS digital elevation model, an structural analysis using Coltop3D software revealed that the basal failure surface of the rockslide is complex, with a $30^{\circ} \mathrm{NW}$ dipping fault plane being the most critical (Redfield et al. 2011). The post failure digital elevation model (DEM) obtained by TLS was compared to a pre failure DEM reconstructed by photogrammetry, indicating that the rockslide volume that failed from the main scar was $20.9 \mathrm{Mm}^{3}$. In addition 7.3 $\mathrm{Mm}^{3}$ sediments were eroded out of the valley and entrained into the avalanche (Yugsi Molina et al. 2012).

The combination of both data was used to establish the rockslide-debris avalanche on land suggesting that failure occurred in two events. The first and main event was composed of a block up to $135 \mathrm{~m}$ in thickness that broke in smaller fragments, slid into the valley and run-up the opposing slope up to $180 \mathrm{~m}$. Further close to the shoreline, run-up was $45 \mathrm{~m}$, however flow direction here had to be nearly valley-parallel. Valley fill entrainment occurred mostly along the valley axis, while along the SE valley slope the rockslide had a net loss of volume (Redfield et al. 2011; Oppikofer et al. 2012). The debris avalanche entered the fjord causing the failure of the delta and a shoreline retreat of $100 \mathrm{~m}$. Following the main event a second compartment of highly fractured rock failed upslope from the main failure and deposited at the slope foot. This deposit necessarily dammed the valley, however the dam did not persist long as no lake sediments have been found. Furthermore the entrainment of debris in the valley undercut its slopes were secondary landslides occurred that deposited on top of the debris avalanche.

This sub-aerial landslide entered the water mass, generating a displacement wave and leaving its imprint on the fjord floor. The debris avalanche descended and accelerated from the sea surface down to $203 \mathrm{~m}$ water depth through a $320 \mathrm{~m}$ wide, $580 \mathrm{~m}$ long, $10-25^{\circ} \mathrm{ramp}$ in the submerged part of the fjord wall (Fig. 14.1b). In turn, a $1.25 \mathrm{~km}$ long section of the northern wall west of the ramp also destabilized. The combined avalanche produced an area of $7.6 \mathrm{~km}^{2}$ of deformation in the basin-plain sediment of the otherwise featureless and smooth fjord floor. The central part of the deformed area is currently deeper with respect to the undeformed floor, which suggests that between 1 and $10 \mathrm{~m}$ of sediment were eroded from an area of $1.85 \mathrm{~km}^{2}$ due to the direct impact of the avalanche (Fig. 14.1b). This depressed area is most evident at the foot of the ramp following three main directions, whereas erosion is more modest further west, thus indicating the area of higher flow energy. The eroded sediment from the central part was folded and piled forming a deformation ring that attains a 
positive relief of up to $12 \mathrm{~m}$ with respect to the undeformed fjord floor, characterized by a series of concentric compressional ridges and a faint frontal depression. In front of the ramp, the area impacted with the strongest energy, the deformation ring has no continuity. This suggests that the sediment was there over-deformed by the arrival of large rock fragments from the sub-aerial landslide, probably pulling it off and forming dozens of up to $70 \mathrm{~m}$ large sediment chunks, which can be observed at the sides of the break-through. These blocks could be formed by rock fragments coated by sediment. The imprint of the Punta Cola landslide can be observed up to $3.5 \mathrm{~km}$ away from the coastline, at the foot of the opposite fjord wall (Lastras et al. 2013).

\subsection{Discussion and Conclusion}

The Aysén event exemplifies the enormous imprint on submarine sediments that a subaerial landslide can leave. The subaerial landslide at Punta Cola caused the failure of a 100-m-wide part of the delta along the shoreline and slope failure on the submarine slope and in addition strong deformation of $7.6 \mathrm{~km}^{2}$ of flat ocean bottom sediments. The subaerial landslide represents only a minor fraction of the total area and volume of the event including its submarine part. In general, several parameters have been taken into account to model the magnitude of displacement waves generated by a landslide impact into a water body including: (i) volume of moving material, and especially the morphology of the front area, (ii) water depth of the water body, (iii) velocity of the slide (e.g. Tinti et al. 1999; Løvholt et al. 2008). However those parameters might not entirely explain the water surface elevation, since the synchronic submarine deformation is not taken into account. In the Aysén fjord event, omitting such deformation might help explaining the discrepancy of the measured run-up along the shorelines in the fjord and the modeled surface elevation (Scheele et al. 2013). Displacement wave modelling should therefore not only take into account the entering of a large rock avalanche in the fjord water mass, but also the sudden upwards movement of the marine sediments.

Acknowledgments This research was supported by Acción Complementaria DETSUFA (CTM2010-09891-E MAR) of the Spanish RTD programme, and a Generalitat de Catalunya "Grup de Recerca Consolidat" grant (2009-SGR 1305).

\section{References}

Blikra LH, Longva O, Braathen A, Anda E, Dehls JF, Stalsberg K (2006) Rock slope failures in Norwegian Fjord Areas: examples, spatial distribution and temporal pattern. In: Evans SG, Scarascia
Mugnozza G, Strom A, Hermanns RL (eds) Landslides from massive rock slope failure. NATO science series, IV. Earth and environmental sciences, vol 49. Springer, Dodrecht, pp 475-496

Hendron AJ Jr, Patton FD (1987) The Vaiont slide; a geotechnical analysis based on new geologic observations of the failure surface. Eng Geol 24:475-491

Hermanns RL, Hansen L, Sletten K, Böhme M, Bunkholt H, Dehls JF, Eilertsen R, Fischer L, ĹHeureux J-S, Høgaas F, Nordahl B, Oppikofer T, Rubensdotter L, Solberg I-L, Stalsberg K, Yugsi Molina FX (2012) Systematic geological mapping for landslide understanding in the Norwegian context. In: Eberhardt E, Froese C, Turner AK, Leroueil S (eds) Landslide and engineered slopes: protecting society through improved understanding. Taylor \& Francis Group, London, pp 265-271

Lastras G, Amblas D, Calafat AM, Canals M, Frigola J, Hermanns RL, Lafuerza S, Longva O, Micallef A, Sepúlveda S, Vargas G, De Batist M, Van Daele M, Azpiroz M, Bascuñán I, Duhart P, Iglesias O, Kempf P, Rayo X (2013) Landslide cause tsunami waves: insights from Aysén fjord, Chile. EOS Trans Am Geophys Union 4(34):297-298

Løvholt F, Pedersen G, Gisler G (2008) Oceanic propagation of a potential tsunami from the La Palma Island. J Geophys Res 113:C09026

Naranjo JA, Arenas M, Clavero, Muñoz O (2009) Mass movementinduced tsunamis: main effects during the Patagonian. Fjordland seismic crisis in Aisén $\left(45^{\circ} 25^{\prime} \mathrm{S}\right)$, Chile. Andean Geol 36:137-145

Oppikofer T, Hermanns RL, Redfield T, Sepúlveda SA, Duhart P, Bascuñan I (2012) Morphologic description of the Punta Cola rock avalanche and associated minor rockslides caused by the 21 April 2007 Aysén earthquake (Patagonia, southern Chile). Revista Asociación Geológica Argentina 69:339-353

Redfield T, Hermanns R, Oppikofer T, Duhart P, Mella M, Derch P, Bascuñán I, Arenas M, Fernández J, Sepúlveda S, Rebolledo S, Loew S, Yugsi Molina F, Abächerli A, Henderson IHC, Jaboyedoff M, Kveldsvik V (2011) Analysis of the 2007 earthquake-induced Punta Cola rockslide and tsunami, Aysén fjord, Patagonia, Chile $\left(45.3^{\circ} \mathrm{S}, 73.0^{\circ} \mathrm{W}\right)$. In: 5 th international conference on earthquake geotechnical engineering, Santiago, paper 12.8

Scheele L, Yugsi Molina F, Oppikofer T, Hermanns RL, Kveldsvik V, Glimsdal S (2013) ICG P10 2006, tsunami modeling and prediction: modeling of the Aysén fjord rock slide tsunami. ICG report 3013-10-1, NGI report 20061073-02-R, p 19

Sepúlveda SA, Serey A (2009) Tsunamigenic, earth-quake-triggered rock slope failures during the 21st of April 2007 Aisén earthquake, Southern Chile $\left(45.5^{\circ} \mathrm{S}\right)$. Andean Geol 36(1):131-136

Sepúlveda SA, Serey A, Lara M, Pavez A, Rebolledo S (2010) Landslides induced by the 2007 Aysen Fjord earthquake, Chilean Patagonia. Landslides 7:483-492

Tappin DR, Watts P, Grilli ST (2008) The Papua New Guinea tsunami of 17 July 1998: anatomy of a catastrophic event. Nat Hazards Earth Syst Sci 8:1-24

Tinti S, Bortolucci E, Armigliato A (1999) Numerical simulation of the landslide-induced tsunami of 1988 on Vulcano Island, Italy. Bull Volc 61:121-137

Van Daele M, Versteeg W, Pino M, Urrutia R, De Batist M (2013) Widespread deformation of basin-plain sediments in Aysén fjord (Chile) due to impact by earthquake-triggered, onshore-generated mass movements. Mar Geol 337:67-79

Yugsi Molina F, Oppikofer T, Hermanns RL, Red-Field TF, Bascuñán I, Loew S, Sepúlveda SA (2012) Mechanism and volume estimation of the 2007 Punta Cola rockslide-debris avalanche using terrestrial laser scanning and aerial photogrammetry. In: Eberhardt E, Froese C, Turner AK, Leroueil S (eds) Landslides and engineered slopes: protecting society through improved understanding, vol 1. Taylor \& Francis Group, London, pp 553-559 